\title{
Resenha
}

\section{The environmentalism of the poor - a study of ecological conflicts and valuation}

\author{
José Augusto V. Pádua *
}

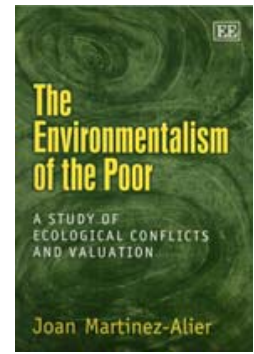

ALIER, Joan Martinez. The environmentalism of the poor - a study of ecological conflicts and valuation. Cheltenham, UK: Edward Elgar, 2002. 312 p.

Joan Martinez Alier é hoje, em nível internacional, um dos nomes mais conhecidos e respeitados da economia ecológica. Sua erudição e conhecimento empírico - demonstrados no seu trabalho como professor catedrático da Universitat Autonoma de Barcelona e presidente da International Society for Ecological Economics resultaram em artigos e livros que são obras de referência.

No entanto, uma das características mais notáveis da atuação de Alier é que suas atividades científicas e acadêmicas nunca sobrepujaram o compromisso político-humanista e o exercício de uma cidadania ativa, preocupada com os pobres. Uma atitude bastante significativa nesses tempos de cinismo e indiferença crescentes nos meios intelectuais. Nesse sentido, as análises teóricas de Alier sobre economia dos recursos naturais são marcadas por décadas de convívio com pescadores, camponeses, pequenos extrativistas e outros moradores das zonas rurais da América Latina, Ásia e África. São indivíduos que sofrem, de modo particularmente acentuado, os efeitos da degradação ambiental - até mesmo pela dependência direta dos fatores climáticos e cíclicos da natureza - sem participar da festa do consumismo que em grande parte provoca a atual crise ecológica global.

Esse novo livro de Alier - cuja edição espanhola saiu em 2004 pela Editorial Icaria, de Barcelona - sintetiza suas preocupações sociais e teóricas, procurando apontar o potencial dos setores mais pobres da população mundial como ativos participantes do esforço pela transformação dos padrões de produção e consumo dominantes no planeta.

Um dos objetivos de The environmentalism of the poor é justamente aproximar as discussões teóricas sobre economia ecológica e ecologia política - especialmente a teoria dos conflitos distributivos na apropriação social dos recursos naturais - das práticas concretas dessas comunidades, rurais ou urbanas, de diferentes partes do mundo. Para isso, são analisadas, entre outras questões, a luta de pescadores contra a destruição dos manguezais pela indústria do camarão, de populações extrativistas florestais contra a contaminação causada pela indústria petrolífera e pelo garimpo do ouro, e de grupos indígenas contra a biopirataria.

Um dos referenciais teóricos e políticos do livro é a busca pela "justiça ambiental”, ou seja, por um padrão de relação social com o meio ambiente que garanta a repartição justa dos bens naturais e impeça que os mais pobres sejam penalizadas pelas atividades poluentes no seu lugar de moradia. Aqui, cabe destacar que num dos

* Professor do IFCS/UFR. Doutor em Ciência Política. E-mail: jpadua@terra.com.br. Endereço: Rua Marquês de São Vicente 226 / 302 B - Gávea. CEP: $22451-040$ Rio de Janeiro - RJ. 
capítulos esse tema é abordado quando o autor descreve as lutas sociais nos EUA e na África do Sul contra a concentração de fábricas poluentes e depósitos de lixo químico nas áreas urbanas mais pobres. Uma luta descrita como combate ao "racismo ambiental", tendo em vista que nessas áreas, a população é majoritariamente negra.

Ao final, a livro de Joan Martinez Alier fala da gritante desigualdade entre as diferentes regiões do planeta em termos de acesso aos recursos naturais. Uma desigualdade que, segundo Alier, revela a verdadeira dívida ecológica que o Primeiro Mundo tem com o restante da humanidade. Uma dívida que simultaneamente tem um componente histórico - como a herança do colonialismo e a histórica queima de combustíveis fósseis pelos países industrializados ao longo dos anos- e um componente de atualidade, pois a cada dia se agrava mais, visto que uma minoria (cerca de $20 \%$ ) da população do planeta se apropria de uma parcela desproporcional (cerca de $80 \%$ ) do ambiente planetário comum. Um problema que fica evidente nas difíceis negociações internacionais sobre o futuro da atmosfera.

Em suma, The environmentalism of the poor - a study of ecological conflicts and valuation é um livro inovador do ponto de vista teórico-analítico e altamente informativo. Em grande parte, seu conteúdo se baseia no contato direto do autor com as diferentes expressões locais da crise ambiental contemporânea. É uma obra que alia erudição e inteligência com o compromisso ético de trabalhar pela construção de um mundo mais justo, democrático e sustentável. 